\title{
Leadership of Schools in Improving the Quality of Education in the Digital Era
}

\author{
Erna Elistiowati ${ }^{1 *}$, Nur Ahyani ${ }^{2}$, Dessy Wardiah ${ }^{2}$ \\ ${ }^{1}$ SMA Negeri 2 OKU, South Sumatra, Indonesia \\ ${ }^{2}$ Universitas PGRI Palembang, Indonesia \\ *Corresponding Author.Email: erna.elistiowati18@gmail.com
}

\begin{abstract}
The digital era is afraid of quality or quality competition, all parties in various fields, one of which is the field of education. In the field of education, the contributions made by school principals and teachers are crucial in improving the quality of formal education. Teachers are required to be able to carry out the learning process as well as possible. This study aims to see and describe the contribution of principal and teacher leadership in improving the quality of learning at SMA Negeri 2 Ogan Komering Ulu. This type of research is a qualitative descriptive study. The data analysis used is to describe the data collected in the form of words, pictures, and not numbers. Data derived from manuscripts, interviews, field notes, documents, and so on, are then described so that they can provide clarity on reality or reality. Based on the research results it is known that; The role of the principal can run well because the stakeholders in SMA Negeri 2 Ogan Komering Ulu work together in improving learning and the efforts of teachers to improve the quality of education related to three things, namely student learning, cooperation with parents, and student morals.
\end{abstract}

Keywords: principal leadership, digital era, education quality, quality improvement, principal contribution

\section{INTRODUCTION}

Life in the era of the industrial revolution 4.0 is a challenge in the world of education. With the existence of the era of the industrial revolution 4.0 , it can be marked by various advances in the online field. For example, mobile, smartphone, internet, computerized artificial intelligence data, and robotization. In educational institutions that are required not only for advances in science and technology, but education must be able to produce quality human resources who can compete at the local, national and international levels. One of the efforts to improve the quality of education in the era of the industrial revolution 4.0, the principal is a very important component to realize leadership in educational institutions.

Educational institutions have a very important role in generating quality national education that is able to compete in this increasingly modern era. If an educational institution is advanced, education in Indonesia will also advance. In this case, it will never be separated from the role of a school principal. The principal is the priest, leader, stakeholder in the school. As the main motor of driving for educational institutions, the principal must work optimally. Because good and bad an institution or organization can be influenced by the leadership style of a school principal. The principal will also want a quality education. So the principal must also pay attention to the human resources (HR) in the institution. In the context of the Indonesian nation, improving the quality of education is a development target in the national education sector and is an integral part of efforts to improve the quality of Indonesian people as a whole.

Education is expected to produce human resources who have competence, competitiveness skills and are able to compete with other nations. In order for Indonesian human resources to be in global competition, everyone is required to have superior competent knowledge, skills and attitudes [1]. The patterns and lifestyles of people will change so rapidly by adopting ways of life that look lucrative and in accordance with modernization and globalization. In the end, it will affect the life order in the nation and the state. Currently, the nations of the world are in an era of digitalization, known as the industrial revolution 4.0.

The success of development in the field of education is known for the quality of human resources involved in the education sector, some of which are school principals and teachers. The principal has an important role in improving the quality of education and is responsible for the implementation of educational activities, school administration, fostering education personnel, and utilizing and maintaining facilities and infrastructure [2]. Seeing the role of the principal, the principal has a challenge to be able to carry out education in the school so that it is focused, planned and sustainable by establishing policies and providing ideas that can improve the quality of education.

Leadership is very important to improve the quality of education, because improving the quality of 
education is the desire of every school. Schools will be able to progress when the principal has visionaries, has managerial skills, and integrity in making quality improvements [3]. One of the important components in improving the quality of education is learning. Learning is a process of interaction between educators or teachers with students and learning resources in a learning environment. Learning is very important because through learning, educators can develop creative thinking that can improve students' thinking abilities, and can increase the ability to construct new knowledge as an effort to increase good mastery of subject matter [4]. Viewed from the institutional school, in terms of supporting the smoothness of learning activities, the principal plays an important role, because it contributes significantly to the quality of learning outcomes. The principal as a leader, manager, driver and activator can make a major contribution to the achievement of educational goals, especially in learning. The quality of education can be seen from the quality of learning. Meanwhile, one important factor that supports the quality of learning is the competence of the teacher.

The contributions made by school principals and teachers are very decisive in efforts to improve the quality of formal education. Teachers are required to be able to carry out the learning process as well as possible. Teachers have a very strategic function and role in improving the quality of learning and therefore teachers themselves are required to have requirements in the form of a certain set of competencies in order to carry out their functions properly.

The teacher plays a central role in controlling teaching and learning activities and is the spearhead that greatly determines how the learning process is carried out. "No teacher, no education, no education, no economic and social development" [5]. In the hands of the teacher, the curriculum, learning resources, facilities and infrastructure as well as the learning climate become something meaningful for students. Therefore, teachers are often the ones to blame when education shows disappointing results, and the quality of teachers is questioned.

\section{METHODS}

This type of research is a qualitative descriptive study. The qualitative descriptive method is used to obtain in-depth data and describe it, a data that contains meaning. Meaning is actual data, definite data which is a value behind the visible data. The purpose of descriptive research is to create a systematic, factual, and accurate description or description of the facts and characteristics of a particular population or object. Descriptive research aims to define a state or phenomenon as it is [6]. This study was used to determine and describe how the leadership contribution of principals and teachers in improving the quality of learning at SMA Negeri 2 OKU.

Data collection techniques in this study were observation, interviews, and documentation. The data analysis used is to describe the data collected in the form of words, pictures, and not numbers. Data derived from manuscripts, interviews, field notes, documents, and so on, are then described so that they can provide clarity on reality or reality. Data analysis in qualitative research was carried out before entering the field, during the field and after finishing in the field. This research uses two kinds of triangulation, firstly triangulation of data sources in the form of observations and interviews with direct sources and triangulation of data collection in the form of documents containing notes related to the data required by the researcher.

\section{RESULTS AND DISCUSSION}

The contribution of the principal in an effort to improve the quality of learning can be seen from the material that will be discussed in the planning, which includes the following areas; Note: Data is taken from school documents and minutes of program preparation meetings. In the field of curriculum / teaching and learning process, the target achieved is the implementation of PAKEM system learning, namely active, creative, effective and fun learning. This is in accordance with the learning concept. This effort is achieved by always providing the facilities and funds needed for learning. In addition to funds and facilities, the role of the principal must always provide guidance and direction through a supervised program, both individually and in groups. In the field of school physical facilities, the need for learning facilities and learning support is achieved. Library room, cooperative, lab. Science, as well as arts, sports, scouting are targets to be achieved, be it new procurement or refinement towards the targeted standards. The creation of shady, green, and beautiful schools is also included in the program to create comfortable learning.

The field of school administration is the achievement by improving the quality of learning by completing all administrative facilities. The role of the principal is quite high as evidenced by the achievement of Predicate A in school accreditation as follows. The institutional sector is the creation of a professional state school status by complementing the school organization. Line organizations and staff are formed by involving elements of the bureaucracy above them and schools and elements of society (stakeholders). The workforce field is the creation of professional staff by providing facilities, bringing in learning experts and sending them to education and training and upgrading as well as sending teachers to postgraduate level education. Achieve teacher welfare by providing regular incentives and incidental intensive forms [7], [8]. In the field of financing, it seeks to create a transparent management that involves all elements of the school and the school committee to discuss funding in a clear, open, democratic manner and is known to all parties.

The field of students is the achievement of the target of graduates who can be relied on to be competent. Non-academic achievement targets are also targeted in the program, including sports, arts, scouting and other extracurricular activities. The participation of students in the education and learning process is not as an educational tool, but as its core. As part of the social network, the education community needs to carry out the task of liberation, in the form of creating new norms, rules, procedures and policies. Parents, teachers, and lecturers must be able to free their children from various 
shackles, not oppress them by setting a single norm or demanding blind obedience [9], [10]. They need to build awareness for the emergence of a dialogical process that brings individuals together to solve their existential problems. It is not beneficial if children and students are given a single choice when they face relative and normative phenomena, including the phenomenon of morality.

The field of the school environment / culture is the creation of a beautiful, shady and beautiful school environment. This is programmed in making gardens, planting shade trees and perfecting school accessories. Greening the class is also the principal concern by involving students and teachers to bring flowers in pots and other hanging flowers. A culture of cooperation between functions within schools, between individuals in schools must be a habit of daily life for school residents. This is in accordance with Robbins' opinion which states that a simple organizational structure has strengths that lie in its speed, flexibility, efficiency to manage and clear accountability [11], [12].

The principal is the driving force for school resources, especially teachers and school employees. So big is the role of the principal in the process of achieving educational goals, so it can be said that the success or failure of a school is largely determined by the quality of the principal, especially in his ability to empower teachers and employees towards a conducive working atmosphere (positive, exciting, and productive). In order to support this, the Principal is required to be: honest, idealistic, intelligent, brave, open, aspirational, communicative, cooperative, creative, agile, like to think positively, full of responsibility.

The following describes the principal's contribution in an effort to improve the quality of learning, which includes his role as an educator, manager, administrator, supervisor, leader, innovator and motivator, including the following. First, the principal as an educator (educator). As an educator the principal is tasked with guiding teachers, education staff, students, following developments in science and technology, and setting good role models [13], [14]. In carrying out its function as an educator, the principal must have the right strategy to improve the professionalism of the teaching staff at his school. Creating a conducive school climate, providing advice to school members, providing encouragement for all education personnel, and carrying out the functions and tasks of organizational leadership.

Efforts that can be made by the principal in improving his performance as an educator, especially in improving the performance of education personnel and learning achievement of students are to include teachers in upgrading or further education. Mobilizing the evaluation team of students' learning outcomes, and using learning time effectively at school, by encouraging teachers to start and end learning according to a predetermined time. And use it effectively and efficiently for the benefit of learning and so on.

Second, the principal as a manager to carry out his role and function as a manager. A person is said to be proportional, if he is attached to an attitude of high dedication to his job. An attitude of commitment to the quality of the process and work results, attitude and continuous innovation, that is, always trying to improve and update the model or how it works in accordance with the guidance of the era. Which is based on a high awareness that the task of educating is to prepare the next generation who will live in their time in the future.

Three, the principal as administrator. Administration is a comprehensive process and consists of various activities or activities in its implementation. As an administrator, the principal is responsible for the smooth running of all administrative work and activities at his school. Administrative activities are all activities related to recording, compiling and documenting school programs and activities. Specifically, the Principal is also required to manage the curriculum, manage the administration of facilities and infrastructure, manage archival administration, and manage financial administration.

The field of school administration is the achievement by improving the quality of learning by completing all administrative facilities. The role of the principal is quite high as evidenced by the achievement of Predicate A in school accreditation as follows. The institutional sector is the creation of professional publicschool status by complementing the school organization. Line organizations and staff are formed by involving elements of the bureaucracy above them and schools and elements of society (stakeholders). The workforce field is the creation of professional staff by providing facilities, bringing in learning experts and sending them to education and training and upgrading as well as sending teachers to postgraduate level education. Achieve teacher welfare by providing regular incentives and incidental intensive forms.

Fourth, the principal as a supervisor. Supervision can also be interpreted as coaching provided to all school staff so that they can improve their ability to develop teaching and learning situations better in accordance with educational goals. The principal as the supervisor has the role and responsibility to foster, monitor, and improve the active, creative, effective, and fun learning process.

Meanwhile, those related to the quality of learning are influenced by the quality of the teaching and learning process. The quality of the teaching and learning process is determined by the various components that are interrelated with one another, namely the input of students, the curriculum, educators and education personnel, infrastructure, funds, management, and the environment. The curriculum is one of the very strategic components of education because it is a set of plans and arrangements regarding the objectives, content, and learning materials as well as the methods used as guidelines for implementing learning activities to achieve educational goals.

In the following efforts of teachers in improving the quality of learning, they already have concepts and programs that are implemented, with the existence of concepts and programs for the process in their implementation it must also be easy. In this implementation, what is important is the preparation and implementation [15], [16], which is described below. For the teacher's efforts to improve the quality of 
learning, there is prepared first, while the preparation for improving the quality of learning is as follows: (1) use of the right curriculum; (2) prepare is learning according to the curriculum; (3). professional teaching staff; and (4) implementation of strategies that suit students. The teacher's efforts to improve the quality of learning are as follows:

a. The teacher's efforts are related to learning

In addition to general education being an important program of this institution, therefore this institution wants students who graduate from the institution to become someone who has skills in the field of general science and also other sciences which are useful for students and families in particular and for society and the State in general. From this desire, institutions, especially teachers, carry out efforts that benefit from learning as follows: (1) prepare the lesson as well as possible; (2) using a variety of methods; (3) a fun way to deliver; and (4) refresh the students so they are not tense.

From the efforts that have been made by institutions and teachers, it is hoped that students will find it easier to learn and so that students understand the aims and objectives of the learning that has been taught in school. And if the quality of education increases, the learning or results of student learning can also increase.

b. Teachers' Efforts to Improve the Quality of Learning Related to Collaboration with Parents

The efforts made by the teacher in improving the quality of learning related to collaboration with parents, namely the teacher making direct relationships with parents, because the parents better understand the real situation of students and provide direction on how to educate good children. By providing this direction, the teacher has the aim that the behavior of students at home is monitored by the teacher. And with the aim that the student's behavior is maintained.

c. Teachers' Efforts to Improve the Quality of
Learning Related to Student Morals
The efforts made by the teacher in improving the quality of Islamic religious education are related to student morals, namely the teacher guiding students directly with the aim that students understand good and bad things. And also, by being taught to pray in congregation before going home from school with the aim of instilling an attitude of discipline and being able to pray in congregation [17]. In addition, the habit of praying in congregation can be carried out not only at school, but also by students at home and life in the community. In addition, researchers also offer several efforts to teachers including:

1) Students must be treated as objects, so they should be encouraged to participate in any planning and decision making related to their activities. What is meant here is that to improve the quality of learning, teachers must involve students in the learning process, in the learning process the teacher must also use a variety of media and methods so that learning is more effective and efficient. With the use of various media and methods, student learning outcomes will increase, with an increase in learning outcomes it means that the quality of education also increases.

2) The circumstances and conditions of students are very diverse, in terms of physical conditions, intellectual abilities, socio-economics, interests, and so on. Therefore, a variety of activities are needed so that each student has a vehicle to develop optimally. In this case the teacher must be able to prepare various types of media in learning, for example, the teacher does not only use the lecture method in learning, but is added with other media so that students can also be creative in learning. With the increase in the abilities of each student, the quality of education also increases.

3) Basically, students will only be motivated to learn, if they enjoy what is being taught. Delivering material from the teacher to students in an attractive manner so that students feel happy and interested in the learning carried out by the teacher, besides that in the learning process the teacher must be able to find a break to provide a little refreshment to students so that students are always comfortable when learning takes place. Thus, students will like the subjects conveyed by the teacher and students become excited about learning. So the quality of education will increase if students are enthusiastic in learning because with the enthusiasm of students in learning it means that the learning objectives of the teacher will be achieved, so that the quality of education also increases.

4) The development of student potential is not only related to the cognitive domain, but also the affective and psychomotor domains.

\section{CONCLUSION}

After carrying out a theoretical study and data analysis based on research and findings in the field regarding the leadership of schools in improving the quality of education in the digital era are as follows:

a. The contribution of the Principal at SMA Negeri 2 Ogan Komering Ulu has an obligation to strive so that all the potential that exists in his institution can be utilized as well as possible in order to achieve the expected improvement in learning. The various roles played by the principal in order to improve the quality of learning at SMA Negeri 2 Ogan Komering ulu include: (a) principal as educator; (b) principal as administrator; (c) principal as supervisor; and (d) principal as manager. All the roles of the principal can run well because the stakeholders in SMA Negeri 2 Ogan Komering Ulu work together to improve the quality of learning.

b. The teacher's efforts to improve the quality of learning at SMA Negeri 2 Ogan Komering Ulu are divided into three stages: (a) the efforts of the teacher to improve the quality of learning related to student learning; (b) the efforts of the teacher to improve the quality of learning related to cooperation with parents; and (c) the 
efforts of the teacher to improve the quality of learning related to student morals.

\section{REFERENCES}

[1] Pahrudin, A., Triyana, E., Oktarisa, Y., Anwar, C. (2019). The Analisys Of Pre-Service Physics Teacher in Scientific Literacy, Jurnal Pendidikan IPA Indonesia, 8(1), 52 - 62

[2] Mulyasa, E. (2004). Menjadi Kepala Sekolah Profesional, dalam Konteks Menyukseskan MBS dan KB. Bandung: Remaja Rosdakarya.

[3] Syafaruddin. (2002). Manajemen Mutu Terpadu dalam Pendidikan. Jakarta: Grasindo.

[4] Sagala, S. (2009). Konsep Dan Makna Pembelajaran. Bandung: Alfabeta.

[5] Surya, M. (2003). Percikan Perjuangan Guru. Semarang: CV Aneka Ilmu.

[6] Sukmadinata, N. S. (2013). Metode Penelitian Pendidikan. Bandung: PT Remaja Rosdakarya.

[7] A. D. Wardani, I. Gunawan, D. E. Kusumaningrum, D. D. N. Benty, R. B. Sumarsono, A. Nurabadi, \& S. Maulina. (2020). "How Teachers Optimize the Role of Classroom Administration in Learning?" In 6th International Conference on Education and Technology (ICET 2020) (pp. 422-426), Atlantis Press, 2020.

[8] S. K. Rofiah, I. Gunawan, and A. D. Wardani. (2020). "What Multimedia Can Teachers Use in Learning?" In 1st International Conference on Information Technology and Education (ICITE 2020) (pp. 691-695), Atlantis Press, 2020.

[9] C. M. Shanti, I. Gunawan, and A. Y. Sobri. (2020). "Relationship of School Visionary Leadership and Organizational Climate with Teacher Performance". In 1st International Conference on Information Technology and Education (ICITE 2020) (pp. 624-629), Atlantis Press, 2020.

[10] A. Prastiawan, I. Gunawan, A. P. Putra, D. A. Dewantoro, P. S. Cholifah, N. L. S. Nuraini, \& E. Surahman. (2020). "Organizational Climate in School Organizations: A Literature Review”. In 1st International Conference on Information Technology and Education (ICITE 2020) (pp. 725728), Atlantis Press, 2020.
[11] Juharyanto, A. Nurabadi, and I. Gunawan. (2020) "Debat Moral Sebagai Upaya Meningkatkan Integritas Kepala Sekolah". JAMP: Jurnal Administrasi dan Manajemen Pendidikan, Vol. 3, No. 3, p. 272-282, 2020.

[12] D. E. Kusumaningrum, R. B. Sumarsono, and I. Gunawan. (2020). "Pengaruh Kepemimpinan Pembelajaran, Kepemimpinan Perubahan, Kepemimpinan Spiritual, Budaya Sekolah, dan Etika Profesi terhadap Kinerja Mengajar Guru". JMSP (Jurnal Manajemen dan Supervisi Pendidikan), Vol. 4, No. 3, 198-219, 2020.

[13] Sultoni, I. Gunawan, and H. Argadinata. (2020). "Dampak Pembelajaran Berkarakter Terhadap Penguatan Karakter Siswa Generasi Milenial". JAMP: Jurnal Administrasi dan Manajemen Pendidikan, Vo. 3, No. 2, p. 51-61, 2020.

[14] E. M. Budiarti, I. Gunawan, and B. A. Pambudi. (2020). "The Effect of Spiritual Leadership and Academic Supervision on Teacher Performance". In 6th International Conference on Education and Technology (ICET 2020) (pp. 157-161), Atlantis Press, 2020.

[15] B. A. Pambudi, and I. Gunawan. (2020). "The Effect of Learning Leadership and Academic Supervision on Teacher Teaching Skills in the Covid-19 Pandemic". In 6th International Conference on Education and Technology (ICET 2020) (pp. 1-5), Atlantis Press, 2020.

[16] N. L. S. Nuraini, P. S. Cholifah, A. P. Putra, E. Surahman, I. Gunawan, D. A. Dewantoro, and A. Prastiawan. (2020). "Social Media in the Classroom: A Literature Review". In 6th International Conference on Education and Technology (ICET 2020) (pp. 264-269), Atlantis Press, 2020.

[17] H. Andriningrum, P. S. Cholifah, I. Gunawan, A. S. M. Harisman, A. F. Putri, T. Amelia, \& D. A. Wulandari. (2020). "Development of Smylings (System for Monitoring Healthy Living Skills) for Health Education in Primary School". In 2020 6th International Conference on Education and Technology (ICET) (pp. 21-25), IEEE, 2020. 